\title{
Haematological reference of snakes: Amazon tree boa (Corallus hortulanus, Linnaeus, 1758) and Burmenese Python (Python bivittatus, Kuhl, 1820) in captive
}

\author{
[Parâmetros hematológicos das serpentes: suaçuboia (Corallus hortulanus, Linnaeus, 1758) e \\ píton birmanesa (Python bivittatus, Kuhl, 1820) em cativeiro] \\ A.E. Quadrini ${ }^{1}$, V.C. Garcia ${ }^{2,3^{*}}$, B.C. Freire ${ }^{1}$, M.F.M. Martins ${ }^{1}$ \\ ${ }^{1}$ Faculdade de Medicina Veterinária - Universidade Cruzeiro do Sul - São Paulo, SP \\ ${ }^{2}$ Instituto Butantan - São Paulo, SP \\ ${ }^{3}$ Faculdade de Medicina Veterinária e Zootecnia - Universidade de São Paulo - São Paulo, SP
}

\begin{abstract}
Hematology has become important for making clinical diagnoses in snakes because maintenance techniques in captivity have been improving and increasing their life expectancy. The emergence of diseases in captivity requires the creation of parameters to understand the species in their healthy state. The possible association between the onset of neoplasia, immunosuppression, and viral infection are also important factors to consider. Thus, hematology is a fundamental tool for observing the responses of animals to diseases and treatments. The present study aims to study hematology between two species of snakes and compare the profiles observed with published results. Blood samples were collected from 16 male and female snakes: seven Corallus hortulanus from the family Boidae and nine Python bivittatus from the family Pythonidae belonging to the Biological Museum of the Butantan Institute, São Paulo, Brazil. Complete blood count results including blood smear, total erythrocyte count, leukocytes, and differential leukocyte count were evaluated. The data obtained in this study could help with the diagnosis, the treatment of snakes in captive conditions and in of nature conservation programs.
\end{abstract}

Keywords: blood count, hematology, snakes, boidae, pythonidae

\section{RESUMO}

A hematologia das serpentes tem se tornado algo de grande importância para o diagnóstico clínico, visto que as técnicas de manutenção em cativeiro vêm aumentando a expectativa de vida. O surgimento de doenças em cativeiro leva à necessidade de criar parâmetros para conhecer as espécies em seu estado hígido. A possível associação entre o surgimento de neoplasias, imunossupressão e infecção viral também é um importante fator a ser considerado. Assim, a hematologia é uma ferramenta fundamental para se observarem as respostas dos animais diante das doenças e dos tratamentos. Nesse contexto, o presente estudo tem como objetivo o estudo hematológico entre duas espécies de serpentes e a comparação dos perfis encontrados com a literatura atual. Foi coletado sangue de 16 serpentes de ambos os sexos da família Boidae: sete Corallus hortulanus, e da família Pythonidae: nove Python bivittatus, pertencentes ao Museu Biológico do Instituto Butantan, São Paulo, Brasil. Foram avaliados o hemograma completo com esfregaço sanguíneo, a contagem total de eritrócitos, os leucócitos e a contagem diferencial de leucócitos. Os dados obtidos neste estudo poderão auxiliar no diagnóstico e no tratamento de serpentes em cativeiro e em programas de conservação da natureza.

Palavras-chave: hemograma, hematologia, serpentes, Boidae, Pythonidae

Recebido em 10 de março de 2017

Aceito em 22 de novembro de 2017

*Autor para correspondência (corresponding author)

E-mail: vivianecgarcia@hotmail.com 


\section{INTRODUCTION}

There are about 3000 species of snakes in the world, Brazil has a rich fauna and is considered one of the largest countries in terms of biodiversity. A total of 386 species belonging to 10 distinct families were identified: Anomalepididae Leptotyphlopidae, Typhlopidae, Aniliidae, Tropidophiidae, Boidae, Colubridae, Dipsadidae, Elapidae, and, Viperidae (Araújo et al., 2009; Bernarde, 2011; Bérnils and Costa, 2012).

The largest non-venomous snakes of Neotropical America are of the Boidae family. This species kills their tusks by constriction (Puorto and França, 2009). In Brazil, the Boidae family is represented by four genus: Eunectes, Boa, Corallus and Epicrates (Noonan and Chippindale, 2006). The Corallus species are distinct members of the neotropical serpent fauna and easily identified as having elongated bodies, sturdy head, slender necks, and prominent lip pits (Henderson, 1997). Corallus hortulanus are the most widespread snakes of this genus, having a great geographical and ecological distribution in relation to the other neotropical snakes (Henderson et al., 1995).

Python is the Pythonidae family, predominantly from tropical plains, mangrove forests, wetland pastures and coastal plains of the Indochinese peninsula and southeast China (O'shea, 2007; Barker and Barker, 2008). Like the Boidae, the Pythonidae family contains large constrictor species, some may be considered "giants", for example, Python reticulatus, is considered the largest snake in the world. In many aspects of their ecology and behavior, pythons resemble each other (O'shea, 2007). Python bivittatus was recently recognized as a species and was previously considered a subspecies of Python molurus (Jacobs et al., 2009).

Although there is great experience in the maintenance and upbringing of captive snakes, there are several difficulties related to early diagnosis, prevention and prophylaxis of infectious diseases. It is believed that there is a direct correlation between these problems and the difficulty of adapting these animals to captivity, since most of them come from nature and are greatly subject to the action of stressors
(Kolesnikovas et al., 2007, Rameh- DeAlbuquerque, 2007).

Hematology is a fundamental tool to observe the response of animals to diseases and treatments, and the determination of health status in reptiles. This is generally based on physical examination, hematological and biochemical values. Conditions such as anemia, inflammatory diseases, parasitism, hematopoietic disorders, and hemostatic alterations can be detected through the blood counts (Grego et al., 2006, Almosny and Monteiro, 2007).

Blood smear evaluation is a powerful diagnostic tool and an essential part of the complete blood count in veterinary medicine (Stacy et al., 2011). The blood cells are commonly found in snake blood can be grouped into three distinct categories: erythrocytes, leukocytes, and thrombocytes (platelet-like cells found in mammals) (Rameh-de-Albuquerque, 2007). Despite the existence of controversies, leukocytes are currently classified as heterophils, lymphocytes, monocytes, eosinophils, basophils and azurophils (Grego, 2006).

Different factors may interfere with blood values such as: animal age, sex (males tend to have higher values of red blood cells in relation to females), season of the year, environmental variations, stress, diet, circulating hormones, temperature and hydration (Grego, 2006; Campbell, 2006; Grego et al., 2014).

The interpretation of hematological data on reptiles is still a challenge compared to domestic animals, due to the lower number of studies and the lack of reference values for most species (Nardini et al., 2013).

The purpose of this study is aimed towards the accomplishment of the hematological analysis, the comparison of the found profiles of the species, comparing the data obtained with the data described in the literature of the snakes belonging to the families Boidae (Corallus hortulanus) and Pythonidae (Python bivittatus) maintained in captivity at the Biological Museum, Butantan Institute.

\section{MATERIAL AND METHODS}

The experiment was conducted at the Biological Museum of the Butantan Institute, São Paulo, 
Brazil, with approval of the Ethical Committee on the Use of Animals of the Butantan Institute (CEUAIB) in a meeting of 02/19/2015; with protocol no 1351/14.

The study was carried out with 16 clinically healthy snakes of the families Pythonidae and Boidae, being nine Python bivittatus and seven Corallus hortullanus, belonging to the Biological Museum of the Butantan Institute. All studied Pythons and the Corallus (n.5014) were born in captivity, while other animals came wildlife.

The method of sample collection was determined by the species, size and volume of blood required to perform these tests. The animals belonging to the experiment were adults and were in conditioned rooms with an average temperature of $25^{\circ} \mathrm{C}$ and $70 \%$ humidity. The collections were carried out in all seasons of the year.

The collection of the blood in the snakes began with the accomplishment of manual containment along with the use of the herpetological hook in order to minimize stress levels as much as possible. The whole procedure was carried out together with an authorized official of the Biological Museum itself and always under the supervision of the Veterinarian in charge of the sector.

Blood sample collection was performed only once in each animal, except in cases of specimen involvement, through puncture of the ventral coccygeal vein, as proposed by Frye (1991), using $3 \mathrm{ml}$ disposable plastic syringes with $0,70 \mathrm{~mm} \times 25 \mathrm{~mm}$ needles, with the blood collected at most $1 \%$ of the animal mass to perform the analyzes.

Soon after blood collection, blood smears were prepared, air-dried, and stained with modified May-Grunwald-Giemsa for leukocyte differential count. A small aliquot of blood (max. 0.3mL) was placed in eppendorf tube containing lytic heparin to determine hematological parameters, handling them carefully to avoid hemolysis of the samples.

After the blood samples were collected, they were sent to the Lab \& Vet clinical laboratory. The review and clinical data were obtained through investigative questionnaires, tabulated in Excel program and consequent statistical analysis results.

\section{RESULTS}

The hematological results obtained for Corallus hortulanus and Python bivittatus were tabulated and their respective means and standard deviation were calculated, organized, and distributed in the tables (Table 1 and 2), as follows:

Table 1. Hematological values of Corallus hortulanus

\begin{tabular}{|c|c|c|c|c|c|c|c|c|}
\hline Species & & Females & & Number & and & $\begin{array}{c}\text { Sex } \\
\text { Males }\end{array}$ & & $\begin{array}{c}\text { Mean } \pm \\
\text { standard } \\
\text { deviation }\end{array}$ \\
\hline Corallus hortulanus & 5006 & 5204 & 5014 & 5201 & 4379 & 4936 & 5223 & \\
\hline Erythocytes x10'6/ $\mu \mathrm{L}$ & 1 & 1,3 & 1,2 & 0,9 & 0,8 & 1,2 & 1,1 & $1 \pm 0,17$ \\
\hline Hematocrit \% & 30 & 23 & 29 & 21 & 20 & 26 & 24 & $24,7 \pm 3,81$ \\
\hline Hemoglobin g/dL & 10,2 & 7,2 & 7,7 & 7,6 & 6,7 & 7,3 & 7,3 & $7,71 \pm 1,14$ \\
\hline $\mathrm{VCM} \mu^{3}$ & 300 & 176,92 & 241,67 & 233,33 & 250 & 216,67 & 218,18 & $233,82 \pm 37,59$ \\
\hline MCHC \% & 34 & 31,3 & 26,55 & 36,19 & 33,5 & 28,08 & 30,42 & $31,43 \pm 3,40$ \\
\hline Total proteins g/dL & 8 & 6,8 & 8 & 6,4 & 6,4 & 7,4 & 7,4 & $7 \pm 0,61$ \\
\hline Leukocytes $/ \mu \mathrm{L}$ & 4.800 & 3.600 & 5.600 & 5.000 & 4.500 & 3.000 & 3.600 & $4.300 \pm 925,56$ \\
\hline Heterophils \% & 56 & 40 & 15 & 44 & 19 & 38 & 47 & $37 \pm 14,87$ \\
\hline Lymphocytes \% & 14 & 20 & 40 & 24 & 30 & 24 & 23 & $25 \pm 8,18$ \\
\hline Monocytes \% & 2 & 0 & 5 & 1 & 2 & 0 & 0 & $1,4 \pm 1,8$ \\
\hline Eosinophils \% & 0 & 0 & 0 & 0 & 0 & 0 & 0 & 0 \\
\hline Basophils \% & 3 & 2 & 0 & 0 & 0 & 0 & 1 & $0,8 \pm 1,21$ \\
\hline Azurophils \% & 24 & 36 & 40 & 31 & 49 & 38 & 29 & $35,28 \pm 8,19$ \\
\hline $\begin{array}{l}\text { Aggregates } \\
\text { trombocytes }\end{array}$ & yes & no & no & no & yes & no & no & \\
\hline Haemogregarines & no & no & no & yes & yes & no & no & \\
\hline Seasons & S & Sp & W & S & W & Sp & Sp & \\
\hline
\end{tabular}

Subtitles: VCM: mean corpuscular volume and MCHC: mean corpuscular hemoglobin concentration. S: summer, A: autumn, W: winter and Sp: spring. 
Haematological reference...

Table 2. Hematological values of Python bivittatus

\begin{tabular}{|c|c|c|c|c|c|c|c|c|c|c|}
\hline Species & & Females & & Number & and & Sex & Males & & & $\begin{array}{c}\text { Mean } \pm \\
\text { standard deviation }\end{array}$ \\
\hline Python bivittatus & 5337 & 5339 & 4789 & 5340 & 5416 & 5474 & 5512 & 5489 & 5338 & \\
\hline 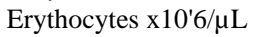 & 0,8 & 1 & 2,1 & 1,3 & 0,8 & 1,2 & 0,7 & 1,1 & 1,1 & $1,2=0,42$ \\
\hline Hematocrit \% & 27 & 20 & 39 & 24 & 26 & 26 & 24 & 25 & 27 & $26,44 \pm 5,17$ \\
\hline Hemoglobin g/dL & 7,4 & 4,7 & 12,7 & 7,1 & 8,3 & 8 & 6,4 & 5,5 & 8,4 & $7,61 \pm 2,29$ \\
\hline $\mathrm{VCM} \mu^{3}$ & 337,5 & 200 & 185,71 & 184,62 & 325 & 216,67 & 342,86 & 227,27 & 245,45 & $251,67 \pm 65,61$ \\
\hline МCHC \% & 27,41 & 23,05 & 32,56 & 29,58 & 31,92 & 30,77 & 26,67 & 22 & 31,11 & $28,33 \pm 3,83$ \\
\hline Total proteins g/dL & 7 & 5,6 & 9,8 & 6 & 6,6 & 6 & 6,6 & 6 & 5,4 & $6,55 \pm 1,32$ \\
\hline Leukocytes $/ \mu \mathrm{L}$ & 4.800 & 7.000 & 6.800 & 6.400 & 2.900 & 3.200 & 5.000 & 5.500 & 2.700 & $4.922 \pm 1.672$ \\
\hline Heterophils \% & 63 & 39 & 30 & 58 & 31 & 47 & 26 & 41 & 43 & $42 \pm 12,52$ \\
\hline Lymphocytes \% & 15 & 11 & 43 & 13 & 28 & 8 & 26 & 19 & 1 & $18,22 \pm 12,56$ \\
\hline Monocytes \% & 0 & 0 & 2 & 0 & 1 & 0 & 0 & 0 & 0 & $0,33 \pm 0,71$ \\
\hline Eosinophils \% & 0 & 6 & 0 & 0 & 0 & 1 & 0 & 1 & 1 & $1 \pm 1,94$ \\
\hline Basophils \% & 0 & 0 & 0 & 1 & 0 & 1 & 0 & 0 & 0 & $0,22 \pm 0,44$ \\
\hline Azurophils \% & 22 & 44 & 25 & 35 & 40 & 43 & 48 & 39 & 55 & $39 \pm 10,49$ \\
\hline $\begin{array}{l}\text { Aggregates } \\
\text { trombocytes }\end{array}$ & no & yes & no & no & no & no & yes & no & no & \\
\hline Haemogregarines & no & no & no & no & no & no & no & no & no & \\
\hline Seasons & $\mathrm{S}$ & A & A & $\mathrm{Sp}$ & $\mathrm{S}$ & $\mathrm{P}$ & $\mathrm{S}$ & A & $\mathrm{Sp}$ & \\
\hline
\end{tabular}

Subtitles: VCM: mean corpuscular volume and MCHC: mean corpuscular hemoglobin concentration. S: summer, A: autumn, W: winter and Sp: spring.

Through blood smears, it was possible to observe hemoparasites (Haemogregarina sp), differentiate leukocytes and observe differences between the blood cells of each specie (Figure 1).

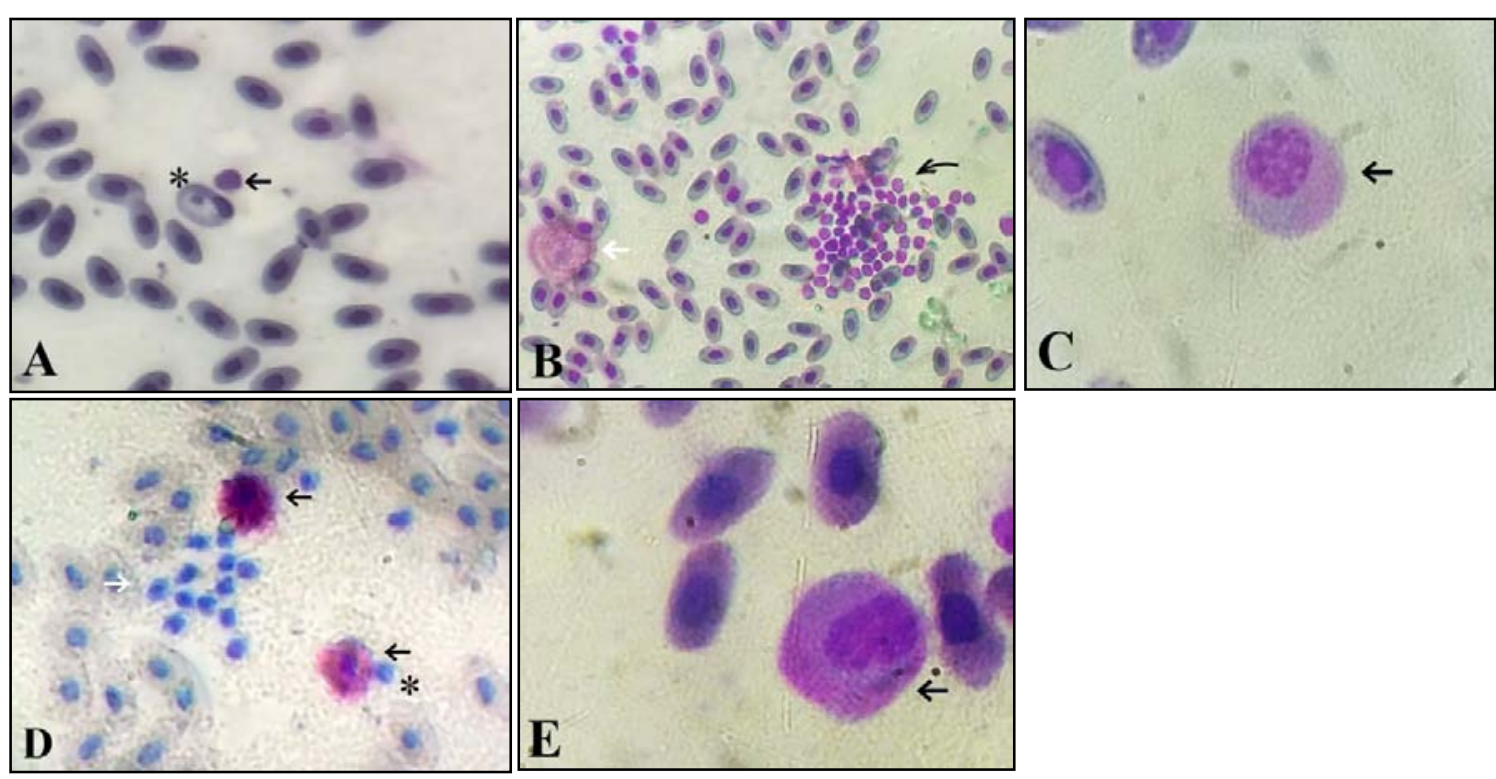

Figure 1. Photomicrography of blood cells stained with May-Grunwald-Giemsa of Corallus hortulanus (A-C) and Python bivittatus (D-E): A) Erythrocyte with Haemogregarina sp (star) and lymphocyte (black arrow), 400X; B) Heterophil (white arrow) and aggregated thrombocytes (black arrow), 400X; C) Azurophil (black arrow), 1000X; D) Heterophils (black arrow), aggregated thrombocytes (white arrow) and lymphocyte (star), 400X and E) Azurophil (black arrow) 1000X.

\section{DISCUSSION}

The type of environment, temperature, humidity, handling, and frequency of feeding as well as diseases in general, influence the hematological values in reptiles in general (Campbell, 2006). Due to these hematological variations, studies on both captivity and free-living reptiles have been increasing. 
In this study blood collection was done in the coccygeal vein, which allowed easy access, despite the non-visualization of the vein. The manual containment is adequate method applied by avoiding the use of chemical containment.

The hemogram was interpreted as the main normal values described in the literature. The hematological values found for Corallus hortulanus (Table 1) have not been specifically described in the literature. Thus, red cell evaluations were performed within the literature standards for snakes with normal hematocrit between $20-40 \%$. Values less than 20\% suggest anemia and greater than $40 \%$ hemoconcentration or polycythemia and hemoglobin. The hematocrit pattern was between 5.5 and 12g/dL (Stacy et al., 2011; Carvalho and Grego, 2013). Corallus snakes of n.5201 and 4379 presented Haemogregarina sp (Figure 1A) on the smear. The haemogregarines are hemoparasites that have asexual reproduction in their definitive host, and this is related to the maintenance of the parasitism for long periods and the increase of the amount when the host is in immunosuppression condition (Oliveira, 2003). The presence of hemoparasite Haemogregarina sp. It is often found in wild snakes and is common in smears (Grego et al., 2006; Carvalho and Grego, 2013). Usually they are not pathogenic and do not distort the host cell, they are found intraerythrocytic. These snakes, although they are in captivity, come from nature, which explains the occurrence of parasitism. The hematimetric data (red blood cells, hematocrit and hemoglobin) of these animals in comparison with the others of the same species present hemolytic anemia. A characteristic that occurs in snakes naturally endoparasites by haemogregarines, hepatozoon, trypanosomes and plasmodium (Thrall et al., 2007; Carvalho and Grego, 2013), corroborating the results.

Due to the use of heparinized tubes to store collected blood, one can observe aggregated thrombocytes, such as the one seen in the Corallus smear of n. 5006 (Figure 1B) and Python n.5339 (Figure 1D) and 5512. In reptiles, thrombocytes are not usually counted, and often, the amount is estimated by smear evaluation. When thrombocytopenia is determined, there may be several causes, and errors in the collection and processing of the material should be ruled out (Stacy et al., 2011).
In the Pythons, the main values of erythrocytes, hematocrit, and hemoglobin (Table 2) were similar to those reported in the literature, with the same standard of values (Campbell, 2006; Carpenter, 2010; Stacy et al., 2011, Carvalho and Grego, 2013). The hematimetric values, VCM and CHCM were found on average for the species (Carpenter, 2010). No hemoparasites were found in blood samples collected from these animals, this fact occurs because all the Python studied are from captivity.

Comparing hematocrits and proteins, one can observe a change in the Corallus of n.5006 and 5014 and in the Python of n.4789 determining a dehydration. And in the Corallus of n. 5201 and 4379 there was a blood loss corresponding to haemolytic anemia caused by hemoparasites.

In the leukogram, changes were observed in both species. Leukocytosis was present in Corallus n. 5014 and 5201 and in Pythons n. 5339, 4789 and 5340. Leukopenia was only observed in the Python of n. 5416 and 5338. In snakes, it is observed that prior to ecdysis there is occurrence of leukocytosis during and after we observed a leucopenia (Carvalho and Grego, 2013). In this study, healthy animals were used without pathological symptoms and, therefore, changes in the leukogram were considered compatible with the ecdysis of the animals evaluated.

Changes in hematological parameters of white cells correspond to ecdysis, season of the year and stress, containment due to the physical conditions of the snakes evaluated. Heterophils (Figure 1B and 1D) make up 20-40\% of the total white blood cell count. The presence of heterophenia in Corallus n. 5014 and 4379 must have been caused by blood collection performed during the winter, a change was observed in colder seasons. Heterophilia was found in the Corallus of n.5006, 5201 and 5223 and in the Python of n. 5337, 5340, 5474, 5489 and 5338. One of the causes of heterophilia is stress (Carvalho and Grego, 2013).

Lymphocytes (Figure 1A and 1D) represent 15$89 \%$ of the total white blood cell count. It is one of the most commonly found cells in the blood smear. Lymphopenia has been observed in Corallus n.5006 and in the pythons 5339, 5340, 5474 and 5338. Lymphopenia is often associated with malnutrition or occurs secondary to a large 
number of diseases caused by stress and immunosuppression (Carvalho and Grego, 2013). In the snakes evaluated, it is very probable that the changes are due to the stress of the containment.

Monocytes represent 0.5 to 3\% of total leukocytes (Stacy et al., 2011). Only the Corallus of n. 5014 showed a monocytosis. Usually, monocytosis is associated with tissue necrosis, suggesting granulomatous inflammatory diseases (Carvalho and Grego, 2013). In this snake no changes suggestive of any disease were clinically evaluated. Thus, we may think of a higher value for the species or an error in the smear reading.

Eosinophils correspond to 7 to $20 \%$ of total leukocytes in reptiles (Stacy et al. 2011). In most species snakes are absent. In the Corallus were not found but in the pythons were found with values between $0-6 \%$ of the total leucocytes. According to Carpenter (2010), the default value for pythons is 0-3\%. Thus, Python n.5339 presented an eosinophilia that, according to Carvalho and Grego (2013), must be related to the season, in this case, autumn.

Basophils constitute $0-4 \%$ of total leukocytes (Carvalho and Grego, 2013). They vary according to the species and the season (decrease in the winter) and in the presence of hemoparasites, no significant changes were observed.

Azurophils (Figure 1C and 1E) may represent up to $35 \%$ of circulating leukocytes. It is the second most abundant leukocyte found in the peripheral blood of the snakes (Carvalho and Grego, 2013). By evaluating the relationship between heterophils (the first leukocyte most found in blood) and azurophils, we determined a normality pattern up to $39 \%$ for Corallus and $43 \%$ for Python. According to Stacy et al. (2011), the increase of azurophils is associated with inflammatory and infectious diseases, particularly in acute processes. As these animals were healthy with the exception of n.4379, this alteration may be occurring because of some undiagnosed disease or an error in the smear reading.

There were no significant variations between males and females. During the seasons, there was heteropenia in the Corallus leucograms in the winter, despite the acclimatized environment. In the literature, hematological variations are described between males and females during the same time of year. Normally, values increased during spring-summer and decreased during autumn-winter, when the animals hibernate in the Northern Hemisphere (Stacy et al., 2011). These variations should be related to extreme climatic variations between summer and winter, which occurs in the Northern Hemisphere, where these papers were carried out. As this research was carried out in the captivity in a controlled environment there were less significant variations.

\section{CONCLUSION}

The hematological values found were important to trace a profile of the species of snakes studied, creating parameters to recognize changes in sick snakes, aiding in diagnosis and treatment. The use of two different species allowed for hematological comparisons. But, the hematological evaluation of the species in the same group allowed to create a parameter to evaluate the abnormalities. As there are few studies related to hematology of snakes described in the literature, the data obtained will aid in the diagnosis and treatment of snakes in captive conditions, as well as in conservation programs, in nature.

\section{ACKNOWLEDGMENTS}

I would like to thank Cruzeiro do Sul University - PIBIC and the Butantan Foundation for funding this project. In addition, to the director of the Biological Museum, Giuseppe Puorto, and collaborators involved in the research.

\section{REFERENCES}

ALMOSNY, N.R.P.; MONTEIRO, A.O. Patologia clínica. In: CUBAS, Z.S.; SILVA, J.C.R.; CATÃO DIAS, J.L. Tratado de animais selvagens. São Paulo: Roca, 2007. p.939-966.

ARAÚJO, F.A.A.; SANTALUCIA, M.; CABRAL, R.F. Epidemiologia dos acidentes por animais peçonhentos. In: CARDOSO, J.L.C.; FRANÇA, O.S.F.; WEN, F.H. et al. (Eds.). Animais peçonhentos no Brasil: biologia, clínica e terapêutica dos acidentes. São Paulo: Sarvier, 2009. p.6-12. 
BARKER, D.G.; BARKER, T.M. The distribution of the Burmese python, python molurus bivittatus. Bull. Chicago Herpetol. Soc., v.43, p.33-38, 2008.

BERNARDE, P.S. Mudanças na classificação de serpentes peçonhentas brasileiras e suas implicações na literatura médica. Gas. Med. Bahia, v.81, p.60-69, 2011.

BÉRNILS, R.S.; COSTA, H.C. Brazilian reptiles: list of species. Version 2012. Available in: $<$ http://www.sbherpetologia.org.br/lista_repteis/ListaR epteis30 Setembro2012-INGLES.pdf>. Accessed in: 21 Nov. 2014.

CAMPBELL, T.W. Clinical pathology of reptiles. In: MADER D.R. (Ed.). Reptile medicine and surgery. St. Louis, Missouri: Elsevier, 2006. p.490-532.

CARPENTER, J.W. Répteis - valores hematológicos e bioquímica sérica de répteis. In: (Ed.). Formulário de animais exóticos. São Paulo: MedVet, 2010. p.96.

CARVALHO, M.P.N.; GREGO K.F. Hematologia e considerações bioquímicas em serpentes - revisão de literatura. Clin. Vet., v.102, p.78-88, 2013.

FRYE, F.L. Hematology as applied to clinical reptile medicine. In: (Ed.). Biomedical and surgical aspects of captive reptile husbandry. Florida: Krieger Publishing, 1991. p.209-277.

GREGO, K.F. Determinação dos níveis séricos de corticosterona e hormônios esteróides sexuais, induzidos pelo estresse da contenção física e da extração de veneno, em Bothrops jararaca (Ophidia: Viperidae). 2006. 130f. Tese (Doutorado em Patologia Experimental e Comparada) - Faculdade de Medicina Veterinária e Zootecnia, Universidade de São Paulo, SP. Available in: $<$ http://www.teses.usp.br/teses/disponiveis/10/10133/t de-02032007-120212/>. Accessed in: 02 May 2014.

GREGO, K.F.; ALVES J.A.S.; RAMEH-DEALBUQUERQUE, L.C.; FERNANDES, W. Referências hematológicas para a jararaca de rabo branco (Bothrops leucurus) recém capturadas da natureza. Arq. Bras. Med. Vet. Zootec., v.58, p.12401243, 2006.

GREGO, K.F.; RAMEH-DE-ALBUQUERQUE, L.C.; KOLESNIKOVAS, C.K.M. Squamata (serpentes). In: CUBAS, Z.S.; SILVA, J.C.R.; CATÃO-DIAS, J.L. (Eds.). Tratado de animais selvagens. São Paulo: Roca, 2014. p.186-218.

HENDERSON, R.W. A Taxonomic review of the Corallus hortulanus complex of neotropical tree boas. Caribb. J. Sci., v.3, p.198-221, 1997.
HENDERSON, R.W.; WALLER, T.; MICUCCI, P. et al. Ecological correlates and patterns in the distribution of Neotropical Boines (Serpentes: boidae): a preliminary assessment. Herpetol. Nat. Hist., v.3, p.15-27, 1995.

JACOBS, H.J.; AULIYA, M.; BÖHME, W. Zur taxonomie des dunklen tigerpythons, Python molurus bivittatus Kuhl, 1820, speziell der population von Sulawesi. Sauria, v.31, p.5-16, 2009.

KOLESNIKOVAS, C.K.M.; GREGO K.F.; ALBUQUERQUE, L.C.R. Ordem Squamata subordem ophidia. In: CUBAS, Z.S.; SILVA, J.C.R.; CATÃO-DIAS, J.L. (Eds.). Tratado de animais selvagens. São Paulo: Roca, 2007. p.68-85.

NARDINI, G.; LEOPARDI, S.; BIELLI, M. Clinical hematology in reptilian species. Vet. Clin. N. Am. Exot. Anim. Pract., v.16, p.1-30, 2013.

NOONAN, B.P.; CHIPPINDALE, P.T. Dispersal and vicariance: the complex evolutionary history of boid snakes. Mol. Phylogenet. Evol., v.40, p.347-358, 2006.

O'SHEA, M. Boas and pythons of the world. Princeton, Oxford: Princeton University Press, 2007. 160p.

OLIVEIRA, P.M.A. Animais silvestres e exóticos na clínica particular. São Paulo: Roca, 2003. p.332-333.

PUORTO, G.; FRANÇA, F.O.S. Serpentes não peçonhentas e aspectos clínicos dos acidentes. In.: CARDOSO, J.L.C.; FRANÇA, F.O.S.; WEN, F.H. et al. (Eds.). Animais peçonhentos no Brasil: biologia, clínica e terapêutica dos acidentes. São Paulo: Savier, 2009. p.124-129.

RAMEH-DE-ALBUQUERQUE, L.C. Aspectos hematológicos, bioquímicos, morfológicos e citoquímicos de células sanguíneas em Viperídeos neotropicais dos gêneros Bothrops e Crotalus mantidos em cativeiro. 2007. 178f. Tese (Doutorado em Patologia Experimental e Comparada) - Faculdade de Medicina Veterinária e Zootecnia, Universidade de São Paulo, São Paulo, SP. Available in: $<$ http://www.teses.usp.br/teses/disponiveis/10/10133/t de-31052007-143116/>. Accessed in: 05 May 2014.

STACY, N.I.; ALLEMAN, A.R.; SAYLER, K.A. Diagnostic hematology of reptiles. Clin. Lab. Med., v.31, p.87-108, 2011.

THRALL, M.A.; BAKER, D.C.; CAMPBELL, T.W. et al. Hematologia e bioquímica clínica veterinária. São Paulo: Roca, 2007. p.259-260. 